\title{
ANASTROPHYLLUM ELLIPTICUM INOUE (JUNGERMANNIALES, MARCHANTIOPHYTA), A NEW SPECIES FOR RUSSIAN LIVERWORT FLORA
}

\section{ANASTROPHYLLUM ELLIPTICUM INOUE (JUNGERMANNIALES, MARCHANTIOPHYTA) - НОВЫЙ ВИД ДЛЯ ФЛОРЫ ПЕЧЁНОЧНИКОВ РОССИИ}

\author{
YURIY S. MAMONTOV ${ }^{1} \&$ ANNA A. VILNET ${ }^{1}$ \\ ЮРИЙ С. МАМОНТОВ ${ }^{1}$, АННА А. ВИЛЬНЕТ ${ }^{1}$
}

Abstract

\begin{abstract}
An integrative taxonomy approach based on analyses of morphological, ecological, geographical and nucleotide sequences (ITS1-2 nrDNA, trnL-F and trnG-intron cpDNA) data allowed determining Anastrophyllum ellipticum Inoue, a species found in the Altai Mts. (South Siberia) and new for Russia. Detail description and illustrations are provided, its morphological differences from related A. lignicola D.B. Schill \& D.G. Long are discussed.
\end{abstract}

Резюме

Комплексный подход, основанный на анализе морфологических, экологических, географических и нуклеотидных (ITS1-2 ядДНК, $t r n \mathrm{~L}-\mathrm{F}$ и интрона гена $t r n \mathrm{G}$ хпДНК) данных, позволил выявить новый вид для флоры печёночников России - Anastrophyllum ellipticum Inoue, найденный в горах Алтая (Южная Сибирь). Приводятся детальное описание и рисунки, обсуждаются морфологические отличия от близкого вида A. lignicola D.B. Schill \& D.G. Long.

KEYWORDS: Anastrophyllum ellipticum, Anastrophyllum lignicola, trnL-F, trnG-intron cpDNA , ITS1-2 nrDNA, Altai Mts., South Siberia, Russia,

\section{INTRODUCTION}

During a field trip in the Katunsky State Nature Biosphere Reserve (the Altai Mountains, South Siberia, Russia) in September 2012, the senior author collected a liverwort specimen which differed from all known Anastrophyllum species in Russia by a combination of the following features: very small size, 2-celled ellipsoid gemmae on the tips of shoots with unmodifed leaves and dioecious condition (only male plants were found). To facilitate determination, we tested this Anastrophyllum specimen for its phylogenetic relationships with other Holarctic Anastrophyllum s.l. taxa with known DNA sequences. On the obtained trees, our Altai specimen was found in one clade with a sample of A. lignicola D.B. Schill \& D.G. Long, kindly provided to KPABG herbarium by Prof. D.G. Long (CHINA: Yunnan Province, Diging Pref., Bai Ma Chan, 6.VI.1993 Long \# 24067). Anastrophyllum lignicola has been recently described by Schill \& Long (2002) and is known from Bhutan and China (Yunnan). However, a comparison of morphological features of both discussed Anastrophyllum specimens revealed some differences. Following a suggestion of Prof. Long, we compared Altaian plants with Japanese species Anastrophyllum ellipticum Inoue (Inoue, 1978) that resembled A. lignicola in morphology. This poorly known species has long been considered as endemic of Japan (Higuchi, 2011), but recently has also been reported from southwest Sichuan, China (Long, 2011). Unfortunately, we were unable to study specimens of A. ellipticum Inoue morphologically and molecularly, but the Anastrophyllum plants from the Altai fit the type description of A. ellipticum perfectly.

In this study, we analyse ITS1-2 nrDNA, trnL-F and trnG-intron cpDNA nucleotide sequences, demonstrate phylogenetic relationships of the new Altai specimen to the known Anastrophyllum s.l. taxa, and provide its morphological description.

\section{MATERIAL AND METHODS}

Taxon sampling. Together with the enigmatic Anastrophyllum specimen from the Altai, our DNA analysis involved $A$. assimile (Hook.) Stephani, A. michauxii (F. Weber) H.Buch, A. lignicola, A. sphenoloboides R.M. Schust., Sphenolobus minutus (Schreb.) Berggr., S. saxicola (Schrad.) Steph. and Crossocalyx hellerianus (Nees ex Lindenb.) Meyl. gathered from different localities of Russia, Norway, South Korea, China, and USA. In total 15 specimens of four Anastrophyllum s.str. species were included in the analyses. Barbilophozia lycopodioides (Wallr.) Loeske was chosen as outgroup basing on our published results (Vilnet et al., 2010). We re-run ITS1-2

\footnotetext{
1 - Polar-Alpine Botanical Garden, Kola Science Centre, Russian Academy of Sciences; Kirovsk-6, Murmansk Province 184256 Russia - Россия 184256, г. Кировск-6 Мурманской области, Полярно-альпийский ботанический сад-институт им. Н.А. Аврорина КНЦ РАН; e-mails: yur-mamontov@yandex.ru, anya_v@list.ru
} 
Table 1. List of taxa, specimen vouchers and GenBank accession numbers. In Anastrophyllum ellipticum, ITS1 and ITS2 have different accession numbers, marked by asterisk * or double asterisk ** correspondingly.

Taxon Specimen voucher (Herbarium)

Anastrophyllum assimile

Anastrophyllum ellipticum

Anastrophyllum lignicola Anastrophyllum michauxi

Anastrophyllum sp. Anastrophyllum sphenoloboides

Barbilophozia lycopodioides Crossocalyx hellerianus

Sphenolobus minutus

Sphenolobus saxicola
Russia: Altai Territory, M. Ignatov, \#4/1 (KPABG)

South Korea, S.-S. Choi, Hepaticae Korea,

Exsiccatae F.II \#51, 115517 (KPABG) 1

South Korea, V. Bakalin, Kor-5-12-11 (VBGI),

115596 (KPABG) 2

U.S.A., N. Konstantinova, A 137-18-95 (KPABG)

Russia: Altai Territory, Yu. Mamontov, 330/2 (KPABG)

China, D. Long, 24067 (KPABG)

Russia: Buryatiya Rep., N. Konstantinova,

17-1-02 (KPABG) 1

Russia: Buryatiya Rep., V. Bakalin, 22-1-27,

102860 (KPABG) 2

Russia: Kemerovo Prov., N. Konstantinova,

35-1a-00, 101837 (KPABG)

Russia: Komi Rep., M. Dulin, Bryophyta rei publicae

Kimi Exciccatae F.I. NN 1-10, 109820 (KPABG)

South Korea, S.-S. Choi, Hepaticae Korea Exsiccatae

F.II \#54, 115520 (KPABG)

Russia: Amur Prov., V. Bakalin, 15-20-00, 101577 (KPABG)

Russia: Murmansk Prov., V. Bakalin, 23-03-01 (KPABG)

Russia: Yakutiya Rep., V. Bakalin, 101592 (KPABG)

Norway: Svalbard, N. Konstantinova, K 50-3-06 (KPABG)

Russia: Murmansk Prov., Konstantinova N., 185-89 (KPABG)

Russia: Kareliya Rep., V. Bakalin, 06.08.1997 (KPABG)

Russia: Sakhalin Prov., Sakhalin I., V. Bakalin,

Exsiccatae \#82 (VLA, KPABG)

Russia: Kareliya Rep., V. Bakalin, 24.07.1998

Norway: Svalbard, N. Konstantinova, K 68-1-06 (KPABG)

Russia: Buryatiya Rep., N. Konstantinova, 123-3-02 (KPABG)
GenBank accession numbers

ITS1-2 trnL-F trnG-intron

KF836651 KF836661 KF836640

KF836650 KF836660 KF836639

KF836652 KF836662 KF836641

EU791776 EU791664 no data

KF836654* KF836664 KF836642

KF836632**

KF836644 KF836665 no data

DQ875125 DQ875087 no data

KF836646 KF836656 KF836635

KF836647 KF836657 KF836636

KF836645 KF836655 KF836634

KF836648 KF836658 KF836637

KF836649 KF836659 KF836638

EU791778 EU791663 no data

KF836653 KF836663 KF836633

EU791777 EU791662 no data

HQ896993 HQ897100 HQ897071

EU791788 AY327780 no data

KF836643 KF836666 no data

EU791790 AY327766 no data

EU791789 EU791667 no data

DQ875124 DQ875086 no data
nrDNA, $\operatorname{trn} \mathrm{L}-\mathrm{F}$ and $\operatorname{trn} \mathrm{G}$-intron cpDNA sequences for twelve specimens, nucleotide data for nine specimens were borrowed from the previous studies (Yatsentyuk et al., 2004; Vilnet et al., 2010; Vilnet et al., 2012). All analyzed specimens are listed in Table 1, including GenBank accession numbers and voucher details.

DNA isolation, PCR amplification and DNA sequencing followed protocols described in Konstantinova $\&$ Vilnet (2011).

Phylogenetic analysis. Three dataset, ITS1-2, trnL$\mathrm{F}, \operatorname{trn} \mathrm{G}$-intron, were automatically aligned in BioEdit 7.0.1 (Hall, 1999) with ClustalW option and then manually corrected. The preliminary phylogenetic analyses revealed incongruence between ITS1-2 and both chloroplast loci data. The topologies obtained from trnL-F and trnG-intron were similar, thus we produced a combined dataset for both cpDNA loci, marked absent trnG-intron sequences for ten samples as missing data. All positions of the ITS1-2 and $\operatorname{trn} \mathrm{L}-\mathrm{F}+\operatorname{trn} \mathrm{G}$-intron alignments were included in the phylogenetic analysis.

Both datasets were analyzed by Maximum Likelihood estimation (ML) with PhyML (Guindon \& Gascuel, 2003) and Maximum Parsimony method (MP) with TNT (Goloboff et al., 2003). The program ModelGenerator
(Keane 1193024931 et al., 2004) determined that the $\mathrm{TrN}+\mathrm{I}+\mathrm{G}$ model was the best-fit evolutionary model of nucleotide substitutions for ITS1-2 dataset and HKY $+\mathrm{I}+\mathrm{G}$ - for $\operatorname{trn} \mathrm{L}-\mathrm{F}+\operatorname{trn} \mathrm{G}$-intron. These models were used in $\mathrm{ML}$ analysis and the heterogeneity rate among sites was modeled using gamma distribution with four rate categories. Bootstrap support (BS) for individual nodes was assessed using a resampling procedure with 500 replicates.

The MP analysis for both datasets involved a New Technology Search with a search for the minimum-length tree by one reiteration and 1000 bootstrap resamplings; the default settings were used for other parameters, indels were taken into account by a modified complex coding algorithm in SeqState (Müller, 2005).

Infrageneric and infraspecific variability of each DNA locus was evaluated as $p$-distances between samples and species calculated in Mega 5.1 (Tamura et al., 2011) using the pairwise deletion option for counting gaps.

\section{RESULTS}

The nucleotide sequences of ITS 1-2 and trnL-F were obtained for 12 samples, trnG-intron - for 10 samples. The parameters of sequence alignments for each studied loci are shown in Table 2. Despite combined trnL-F+trnGintron aligned sequences were $23 \%$ longer than ITS 1-2 
Table 2. Characteristics of performed ITS1-2, $\operatorname{trn} \mathrm{L}-\mathrm{F}$, $\operatorname{trn} \mathrm{G}$-intron nucleotide alignments.

\begin{tabular}{llllllll} 
& \multicolumn{2}{l}{ Conservative sites } & \multicolumn{3}{c}{ Variable sites } & \multicolumn{2}{c}{ Parsimony-informative sites } \\
& Totall sites & base pairs & $\%$ & base pairs & $\%$ & base pairs & $\%$ \\
ITS1-2 & 848 & 683 & 80.54 & 157 & 18.51 & 90 & 10.61 \\
$\operatorname{trn}$ L-F & 476 & 421 & 88.44 & 53 & 11.13 & 32 & 6.7 \\
$\operatorname{trn}$ G-intron & 617 & 564 & 91.41 & 48 & 7.78 & 12 & 1.9 \\
$\operatorname{trn}$ L-F+trnG-intron & 1093 & 985 & 90.12 & 101 & 9.24 & 44 & 4.03 \\
\hline
\end{tabular}

ones, both cpDNA loci were in $10 \%$ more conservative than ITS1-2, and number of nested variable and parsimony-informative sites was half as much as for ITS1-2.

The MP analysis of ITS1-2 dataset yielded two equally parsimonious trees 322 steps long, with $\mathrm{CI}=0.814286$ and $\mathrm{RI}=0.856618$ calculated in Mega 5.1. A single tree which was 163 steps long was found in MP analysis for trnL$\mathrm{F}+$ trn $\mathrm{G}$-intron, $\mathrm{CI}=0.878049$ and $\mathrm{RI}=0.883721$. The arithmetic means of Log likelihood obtained in ML estimation were 2414.716403 for ITS 1-2 dataset, 2184.997967 for $\operatorname{trn} \mathrm{L}-\mathrm{F}+\operatorname{trn} \mathrm{G}$-intron.

Tree topologies obtained by the two methods for each data set were highly congruent, thus bootstrap support (BS) values for ML trees in Figs. 1-2 are indicated from both ML and MP analyses. The studied samples of the genus Anastrophyllum $\mathrm{s}$. str. united in one clade (more than 94\% BS in all trees). The incongruence between topologies calculated from nuclear and chloroplast datasets consists in different relationships of a subclade composed of the tested Anastrophyllum species and A. lignicola. On ITS topology, it is in sister affinity to Anastrophyllum assimile-subclade (66\% BS in $\mathrm{ML}$, without support in MP), on trn L-F+trnG-intron topology - to A. michauxii + A. sphenoloboides-subclade $(55 \%$ $\mathrm{BS}$ in ML, $61 \% \mathrm{BS}$ in MP). The phylogenetic relationship of the tested Anastrophyllum species and A. lignicola from cpDNA dataset obtained lower support than from ITS1-2 (64\% BS in ML and 66\% BS in MP opposite to $99 \%$ and $82 \%$, respectively). Four samples of $A$. assimile were distributed into two subclades, separated by long branches comparatively with the branch length in subclades of $A$. sphenoloboides or A. michauxii. The sample of Anastrophyllum sp. from Amur Province (Udokan Range) determined by collector V. Bakalin as Anastrophyllum michauxii was phylogeneticaly distinct from $A$. michauxii-subclade and got placed into a separate phylum in relation to $A$. michauxii $+A$. sphenoloboides-subclade in all topologies (Figs. 1, 2). Representatives of genera Sphenolobus and Crossocalyx located in separate clades diverged in ITS1-2 and trnL-F+trnGintron calculations.

For infraspecific and infrageneric $p$-distance calculations, samples were grouped according to clades and phyla obtained in phylogenetic reconstruction. Nine groups were segregated, Anastrophyllum sp., S. saxicola were placed into monotypic groups, samples of $A$. assimile from South Korea were put into a separate group, $A$. lignicola and the tested Altaian Anastrophyllum species were combined in one group. The results of the analyses are summarized in Table 3 . The infraspecific variability was detected in all multiply sampled species in ITS1-2.
It counts less than $1 \%$ in $A$. sphenoloboides, $A$. assimile (Altai and USA) and S. minutus. Crossocalyx hellerianus, A. michauxii, and $A$. assimile from South Korea appear to be more variable taxa $(>1 \%)$ in ITS1-2. The values of $p$-distances in trn L-F are zero or less than $1 \%$ in all taxa with an exception of $C$. hellearianus which could be explained by incorrect sequence reading in accession AY327780 previously deposited in GenBank. Due to the absence of sequence data, $p$-distances for $\operatorname{trn} \mathrm{G}$ intron were calculated only for $A$. michauxii and $A$. assimile from South Korea. A. lignicola and the tested Anastrophyllum species differ from each other by $0.8 \%$ in ITS $1-2$ and $0.4 \%$ by $\operatorname{trnL-F}$, differences from other species varyfrom $0.9 \%$ for $A$. michauxii and A. sphenoloboides in trnL-F to $6.9 \%$ for Anastrophyllum sp. in ITS1-2. Two samples of $A$. assimile from South Korea are genetically more distinct from each other than samples from Altai Territory and USA, both subclades of $A$. assimile also highly differ genetically. $P$-distances between species demonstrated that Anastrophyllum sp. differs almost equally from both $A$. michauxii and $A$. sphenoloboides.

\section{DISCUSSION}

Nowadays exploring DNA data in species identification is becoming a routine procedure. Unfortunately, nucleotide sequence data were obtained for no more than $10 \%$ of all known Anastrophyllum s.l. species (not synonymized binomials). A single example of special taxonomical study based on integrative approach to morphological, ecological and molecular data was the study implemented to prove the species status of $A$. alpinum Steph., which had been synonymized previously with $A$. joergensenii Schiffn. (Long et al., 2006). Other published data on the genus Anastrophyllum s.l. concern predominantly liverwort molecular phylogenetic and taxonomic studies (Schill et al., 2004; Vilnet et al., 2010) or estimation of liverwort divergence time (Feldberg et al., 2013). More or less representative data of infraspecific DNA variability in trnG-intron and rps 4 were obtained only for A. tubulosum (Nees) Grolle, A. auritum (Lehm.) Stephani and A. (Sphenolobus) minutum (Schreb.) R.M. Schust. by de Roo et al. (2006).

The tested Anastrophyllum plants from the Altai and A. lignicola were found in one clade. A low level of molecular differentiation suggests their recent divergence compared with other species of this genus (Table 3). Morphologically plants from the Altai are similar to both A. ellipticum and A. lignicola in size and dioecious condition. At the same time, only male shoots were found in our Altaian sample, which is the case known for A. ellipticum, whereas the Chinese sample of $A$. lignicola in- 


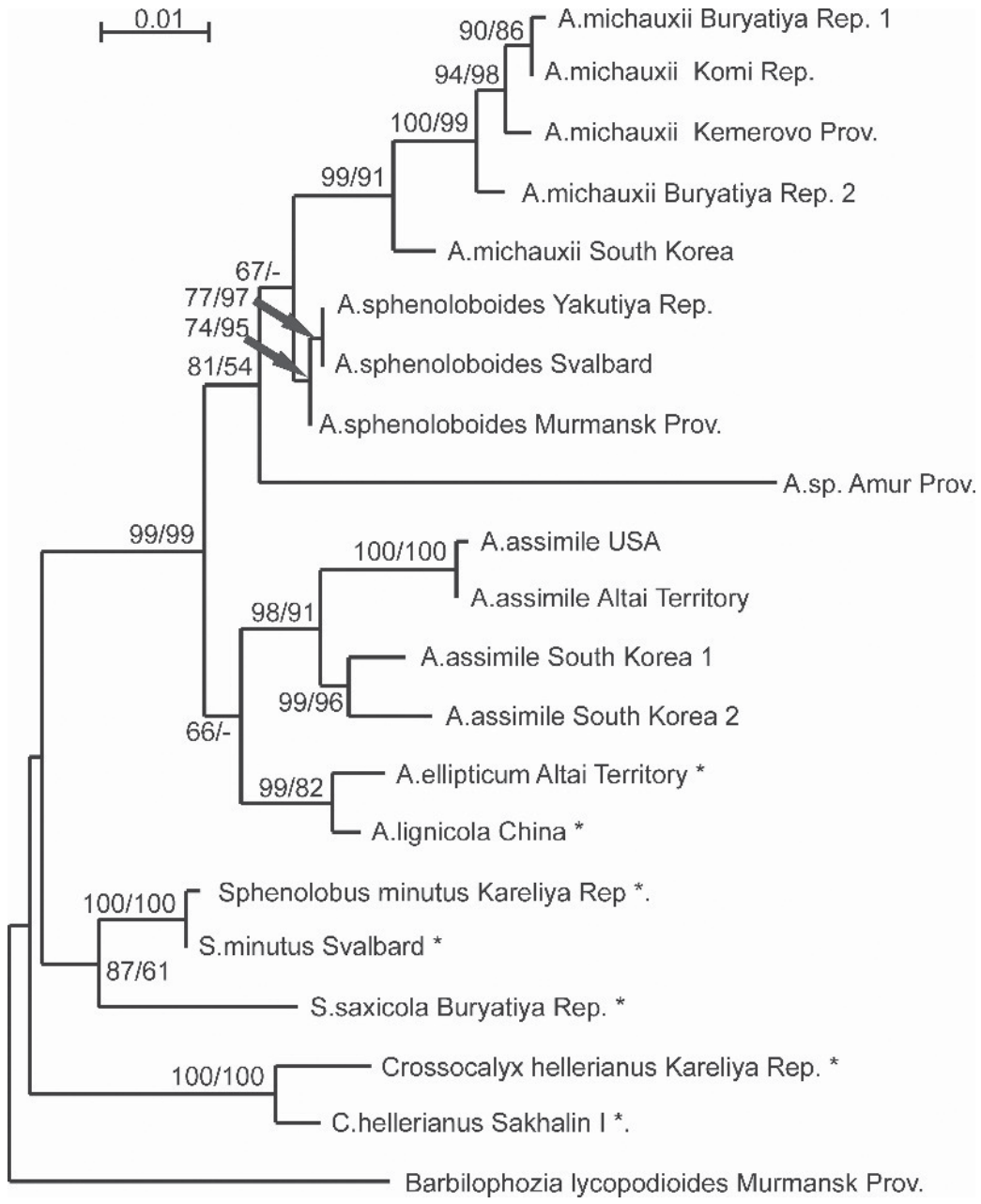

Fig. 1. Maximum likelihood phylogenetic tree for the genus Anastrophyllum and related taxa based on ITS1-2 nrDNA nucleotide sequences. Bootstrap support values over $50 \%$ are indicated from ML/MP analyses. Species with ambiguous position in $\mathrm{ML}$ tree constructed on $\operatorname{trn} \mathrm{L}-\mathrm{F}-\operatorname{trn} \mathrm{G}-\mathrm{in}$ tron dataset are marked by asterisks. cludes both male and female plants as noted in its type description. The tested Anastrophyllum specimen and $A$. ellipticum (as described by Inoue, 1978) are characterized by uniformly 2-celled gemmae that are located at the tips of shoots with unmodifed leaves. Anastrophyllum lignicola produced 1-2-celled gemmae on ascending to erect gemmiferous shoots with reduced and appressed leaves (like those of Crossocalyx hellerianus and Sphenolobus minutus). Basing on morphological investigations, we doubt to classify the tested Altaian Anastrophyllum species to $A$. lignicola. Molecular differentiation between them also implies that the species are most likely different due to the level of ITS1-2 sequence variation compared with more or less morphologically invariable A. spenoloboides, $A$. assimile from USA and Altai Territory, Sphenolobus minutus (Table 3). Taking into account also similar habitat preference, we attribute the Anastrophyllum specimen from the Altai to $A$. ellipticum

Further we provide description of Anastrophyllum ellipticum Inoue based on the specimen from Altai Mts.

Anastrophyllum ellipticum Inoue - Bull. Nat. Sci. Mus., Ser. B, 4: 13. f. 1-2. 1978.

Fig. 3.

Plants brownish-green, with no trace of secondary red or purple pigmentation, grow as single shoots among other liverworts. Shoots 2.25-5.0 mm long, 0.25-0.8 mm wide, ascending. Stem $80-110 \mu \mathrm{m}$ in diameter, pale brown, 6-8 cells across, with 1-2-layered cortex of thick-walled cells gradually draging into the medullary cells nearly as large as the cortical and equally thick-walled. Leaves remote, erect to obliquely spreading from somewhat seating base, not decurrent on both sides, entire-margined, loosely to distinctly conduplicate, ovate to elliptical when flattened, $290-350 \times 390-490 \mu \mathrm{m}, 1.35-1.38$ times as long as wide, bilobed to $0.3-0.37$ of the length, sinus rounded to subacute. Lobes equal to subequal, triangular, apex acute to obtuse, or narrowly rounded. Leaf cells nearly equally thick-walled with indistinct bulging trigones; cuticle covered by fusiform to rounded low papillae. Cells of lobeapex and margins rounded-quadrate to slightly elongate, 1-1.6 times as long as wide, $9-15 \times 13-22 \mu \mathrm{m}$, midleaf cells $10-17 \times 16-26 \mu \mathrm{m}, 1-1.7$ times as long as wide. Gemmae yellowish to reddish, elliptical to fusiform in outline, straight or somewhat incurved, smooth or with scarce angulation, 2-celled, 8.5-12.5×20-29 $\mu \mathrm{m}$, (1.7-)2.5(-3.4) times as long as wide. Gemma formation limited to the apices of shoots with unmodified leaves.

Plants dioecious. Male shoots were found only. Androecia intercalary, with bracts in 1-3 pairs; bracts similar to leaves, but strongly concave at base and more markedly canaliculate; antheridia globose, 1 per bract. 


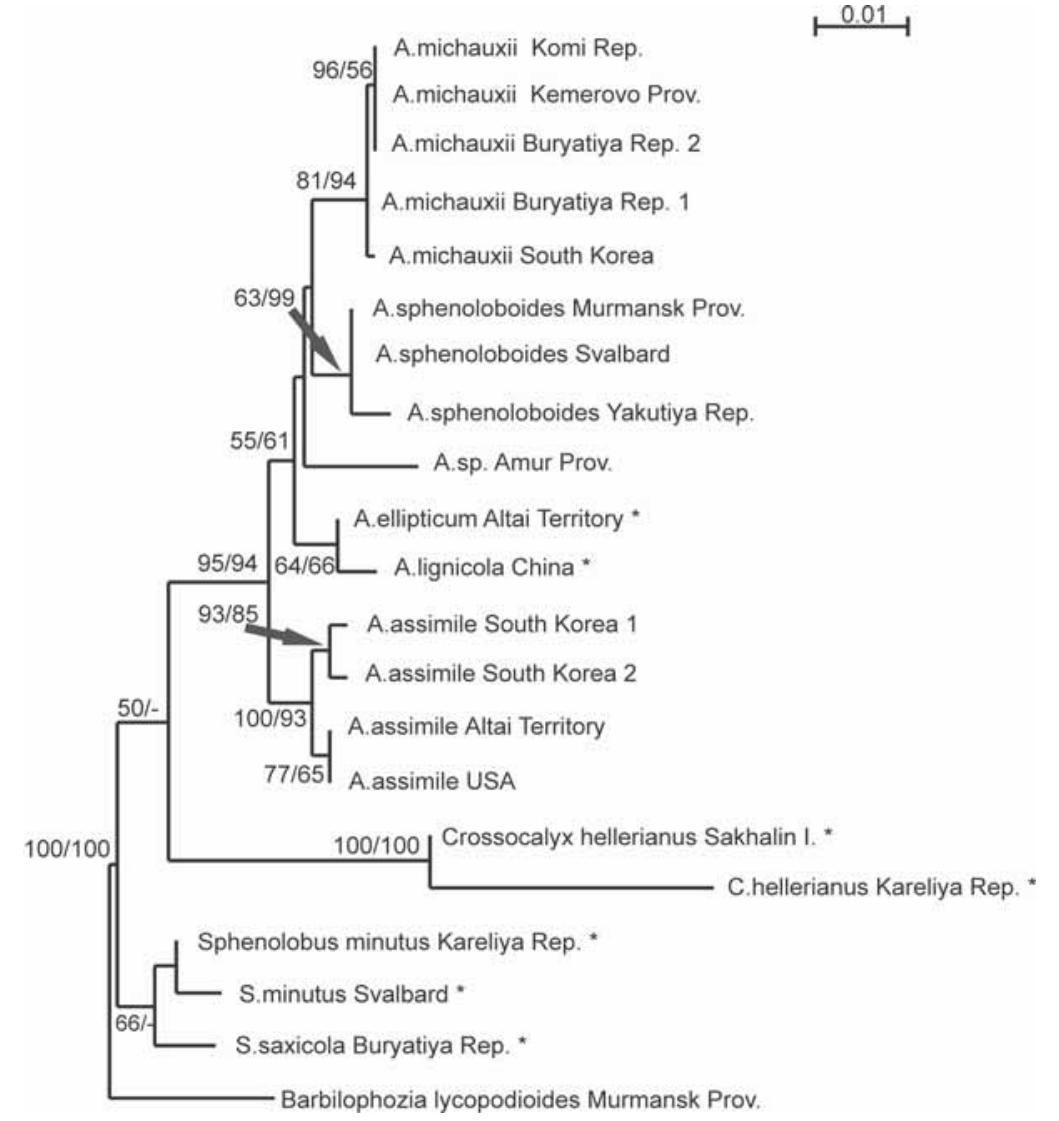

Fig. 2. Maximum likelihood phylogenetic tree for the genus Anastrophyllum and related taxa based on combined trnL-Ftrn G-intron nucleotide sequences. Bootstrap support values over $50 \%$ are indicated from ML/MP analyses. Species with ambiguous position in ML tree constructed on ITS1-2 nrDNA dataset are marked by asterisks.

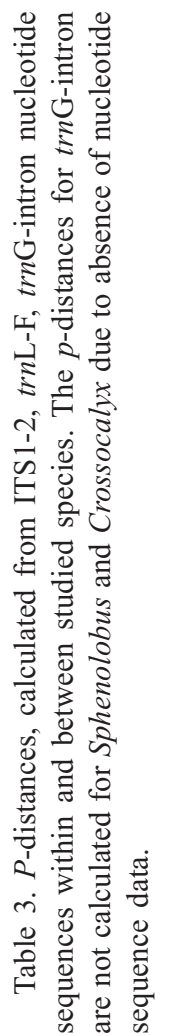

Variation and differentiation: The Altaian plants deviate in some dimensions from the Inoue's description of Anastrophyllum ellipticum (Table 4). Particularly, the Japanese plants are larger, with broader leaves (usually length to width ratio 1-1.2:1 (vs. 1.35-1.38:1), and more deeply bilobed, to about $0.37-0.50$ of the length. In contrast, the gemmae of Japanese plants are slightly smaller, and have lower length/ width ratio (Table 4). Anastrophyllum lignicola hardly differs from both Japanese and Altaian A. ellipticum in size characters, but is distinguished in having ascending to erect gemmiferous shoots with reduced and appressed leaves (Schill \& Long, 2002: Fig. 1), and by gemmae morphology. The gemmae of A. lignicola are 1-2-celled, ellipsoid to rounded, and broader (Fig. 4) than those in A. ellipticum. Only male plants are still known for $A$. ellipticum, whereas both male and female shoots were common in one sample of $A$. lignicola. These two species differs also by their ecology. Anastrophyllum ellipticum was collected exclusively on decaying wood (like Crossocalyx hellerianus), whereas A. lignicola grows on rotten logs and stumps, but occasionally on living tree trunks (Shill \& Long, 2002). It should be noted that these two species could be misidentified in the southwestern China where both of them are known. 
Table 4. A comparison of Anastrophylum ellipticum and A. lignicola.

$\begin{array}{llll}\text { Character } & \begin{array}{l}\text { A. ellipticum } \\ \text { Altai }\end{array} & \begin{array}{l}\text { A. ellipticum } \\ \text { Japan, type description }\end{array} & \begin{array}{l}\text { A. lignicola } \\ \text { Yunnan }\end{array} \\ \text { Shoot width, } \mathrm{mm} & 0.25-0.8 & 0.6-0.8 & \text { to } 1.4 \\ \text { Shoot length, } \mathrm{mm} & 2.25-5.0 & 8-15 & \text { to } 14 \\ \text { Stem diameter, } \mu \mathrm{m} & 80-110 & 100-130 & (90-) 120-180(-220) \\ \text { Leaf width, } \mu \mathrm{m} & 290-350 & (350-) 380-420 & (280-) 400-500(-790) \\ \text { Leaf length, } \mu \mathrm{m} & 390-490 & 400-450 & (320-) 400-550(-820) \\ \text { Gemmae width, } \mu \mathrm{m} & 8.5-12.5 & 8-10 & 8-15 \\ \text { Gemmae length, } \mu \mathrm{m} & 20-29 & 20-28 & 15-27 \\ \text { Gemmae length/width ratio } & (1.7-) 2.5(-3.4) & (1.75-) 2.3(-2.8) & (1.1-) 1.7(-2.1)\end{array}$

Ecology and distribution: Our specimens of Anastrophyllum ellipticum were collected in the Katunsky Range (49 $56^{\prime} \mathrm{N}, 85^{\circ} 51^{\prime} \mathrm{E}, 1700 \mathrm{~m}$ alt.) of the Altai Mts. (Republic of Altai). It was growing on decaying wood of a large log (probably of Pinus sibirica Du Tour) lying over the water of a rivulet in a subalpine coniferous grassmoss forest dominated by Pinus sibirica and Picea obovata Ledeb. and containing an understorey of Abies sibirica Ledeb., Spiraea L. sp., Juniperus L. sp., Vaccinium vitis-idaea L., and $V$. myrtillus L. In this habitat, Anastrophyllum ellipticum was found as single shoots in mixed mats composed by Blepharostoma trichophyllum (L.) Dumort., Cephalozia bicuspidata (L.) Dumort., C. lunulifolia (Dumort.) Dumort., Lepidozia reptans (L.) Dumort., Lophozia lantratoviae Bakalin, L. ventricosa var. longiflora (Nees) Macoun, Riccardia palmata (Hedw.) Carruth., Schistochilopsis incisa (Schrad.) Konstant., and Tritomaria exsecta (Schmidel ex Schrad.) Schiffn. ex Loeske. The type locality of Anastrophyllum ellipticum is Gongen Peak of Southern Yatsugatake Volcanic Group (35 $58^{\prime} \mathrm{N}, 138^{\circ} 22^{\prime} \mathrm{E}$ ) located in the Nagano Pref., Honshu, Japan (Inoue, 1978). It was collected on decaying wood in subalpine (ca. $2300 \mathrm{~m}$ alt.) coniferous forest dominated by Tsuga diversifolia (Maxim.) Mast. - Abies veitchii Lindl., with Siberian dwarf pine Pinus pumila (Pall.) Regel also growing in this subalpine zone. This species was associated with Tritomaria exsecta, Bazzania denudata (Torr. ex Gottsche, Lindenb. $\&$ Nees) Trevis., Scapania ampliata Steph., and several mosses (Inoue, 1978). Recently Anastrophyllum ellipticum has also been found in Southwest Sichuan (about $28^{\circ} 54^{\prime} \mathrm{N}, 101^{\circ} 41^{\prime} \mathrm{E}$ ), China (Long, 2011); the area with subtropical highland climate. In this area, A. ellipticum was collected in conifer-dominated (Abies Mill., Picea A. Dietr. and Larix Mill. species) humid forests (about 3300-4200 m alt.) that contained an understorey of smaller woody broadleaves, such as Acer L., Betula L., Rhododendron L. and Sorbus L. species. Anastrophyllum ellipticum was found there as common on rotten stumps and logs, where Jamesoniella (Spruce) Carrington, Schistochilopsis incisa and Tritomaria exsecta grow as well (Long, 2011). On the basis of the above it can be assumed that Anastrophyllum ellipticum is a mountain species with a disjunctive, presumably relic Asian distribution.
Specimens examined: Russia: Altai Republic, Katunskiy State Biosphere Reserve, Katunskiy Range, Poperechnaya River valley, 19.IX.2012 Mamontov \# YuSM-330-2-2 (KPABG); idem, 19.IX.2012 Mamontov \# YuSM-330-2-5 (KPABG); idem, 19.IX.2012 Mamontov \# YuSM-330-2-6 (KPABG); idem, 19.IX.2012 Mamontov \# YuSM-330-2-7 (KPABG).

\section{ACKNOWLEDGEMENTS}

We cordially thank Prof. D.G. Long for providing a specimen of Anastrophyllum lignicola from China and Dr. M. Ignatov for comprehensive help in preparation of the paper draft . We are deeply obliged to T.V. Yashina (Katunsky State Nature Biosphere Reserve) for help in organizing the field trip in the Katunsky Range, Altai Mts. The research was partially supported by Russian Foundation for Basic Research 12-04-01476, 13-0401427 and 13-04-90728.

\section{LITERATURE CITED}

DE ROO, R.T., T.A. HEDDERSON \& L. SÖDERSTRÖM 2007. Molecular insights into the phylogeny of the leafy liverwort family Lophoziaceae Cavers. - Taxon 56: 310-314.

FELDBERG, K., J. HEINRICHS, A.R. SCHMIDT, J. VÁŇA \& H. SCHNEIDER 2013. Exploring the impact of fossil constraints on the divergence time estimates of derived liverworts. - Plant Syst. Evol. 299: 585-601.

GOLOBOFF, P., S. FARRIS \& K. NIXON 2003. TNT (Tree analysis using New Technology) (BETA) ver. 1.0. Program and documentation, available from the authors, and at www.cladistics.com/ aboutTNT.html.

GUINDON, S. \& O. GASCUEL 2003. A simple, fast, and accurate algorithm to estimate large phylogenies by maximum likelihood. - Systematic Biology 52: 696-704.

HALL, T. A. 1999. BioEdit: a user-friendly biological sequence alignment editor and analysis program for Windows 95/98/NT. - Nucl. Acids. Symp. 41: 95-98.

HIGUCHI, M. 2011. Endemic species of bryophytes in Japan. - Bull. Natn Sci. Mus., Ser. B. (Bot.) 37: 117-126.

INOUE, H. 1978. Anastrophyllum ellipticum Inoue (Sp. Nov., Hepaticae) from Japan. - Bull. Natn. Sci. Mus., Ser. B. (Bot.) 4: 13-17.

KATAGIRI, T. \& T. FURUKI 2012. Checklist of Japanese liverworts and hornworts. - Bryological Research 10: 193-210.

KEANE, T. M., T. J. NAUGHTON \& J. O. MCINERNEY 2004. ModelGenerator: amino acid and nucleotide substitution model selection. Available from: http://bioinf.may.ie/software/modelgenerator/

KONSTANTINOVA, N. A. \& A. A. VILNET 2011. Jubula hutchinsiae ssp. caucasica subsp. nov. (Jubulaceae, Marchantiophyta) - new taxon from western Caucasus. - Arctoa 20: 227-238.

LONG, D.G. 2011. Bryophyte exploration of South-west Sichuan, China. - Field Bryology 103: 32-39.

LONG, D.G., J.A. PATON, J. SQUIRRELL, M. WOODHEAD \& P.M. 


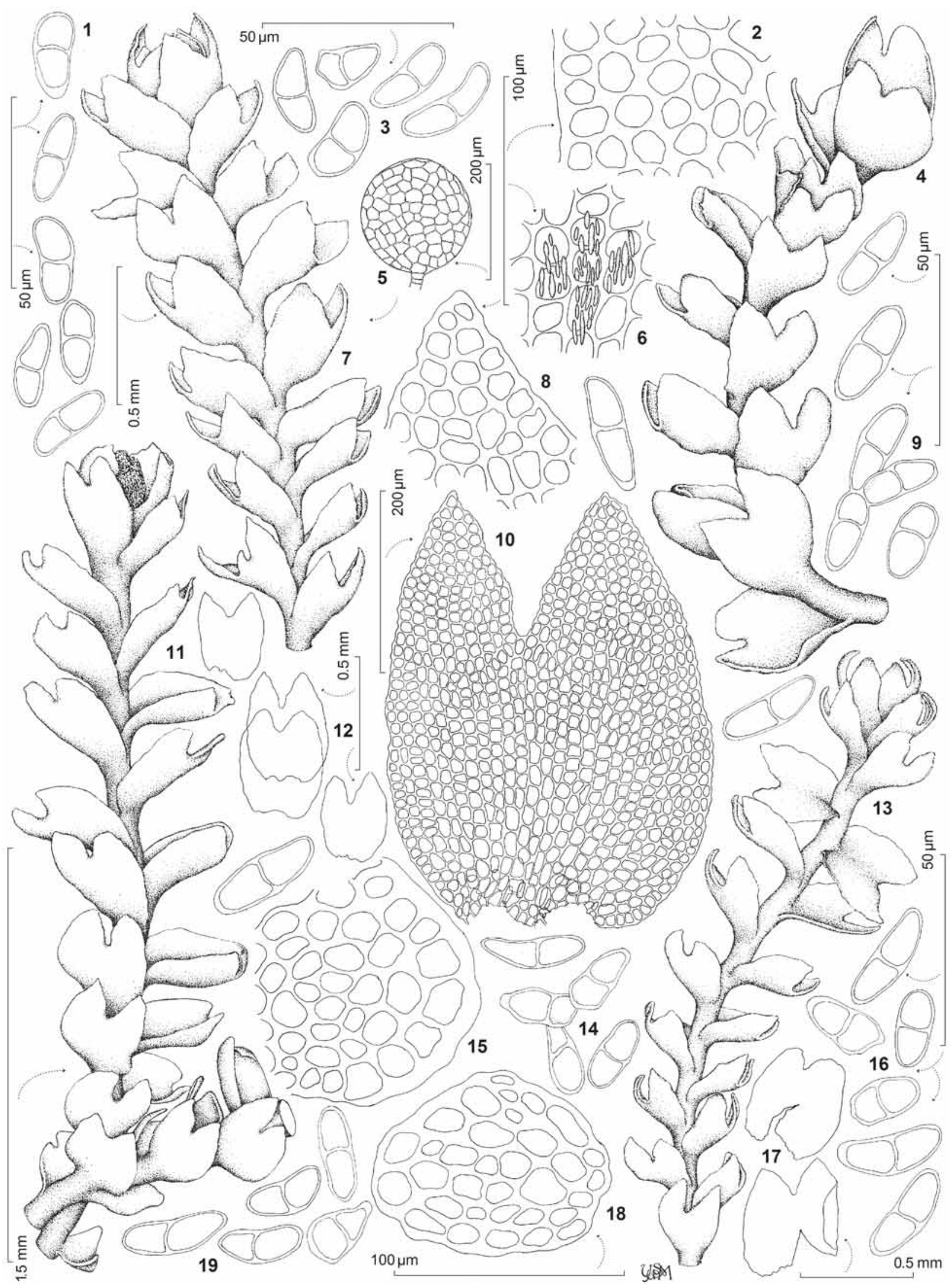

Fig. 3. Anastrophyllum ellipticum: 1, 3, 9, 14, 16, 19 - gemmae; 2 - cells of the leaf middle; 4 - habit, lateral aspect; 5 - an antheridium; 6 - leaf cells near the base, with striolate papillose cuticle indicated; 7, 11, 13 - habit, postical aspect; 8 - leaf lobe apex; 10 - an enlarged leaf with cells indicated; 12 - leaves; 15, 18 - stem cross section, 17 - two male bracts. All from Altai Republic, 19.IX.2012 Mamontov \# YuSM-330-2-2 (KPABG). 


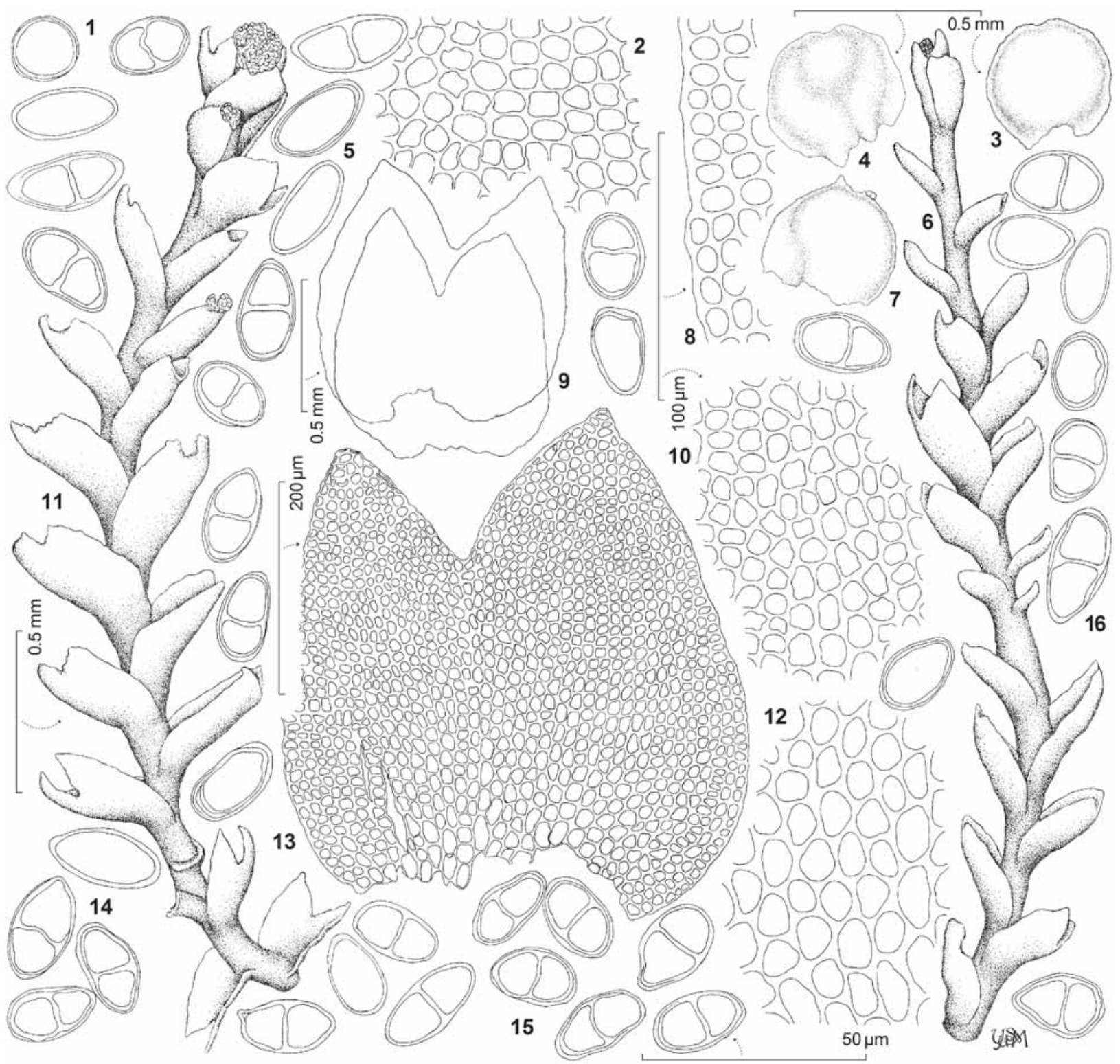

Fig. 4. Anastrophyllum lignicola: 1, 5, 11, 14-16-gemmae; 2 - cells of leaf lobe middle; 3, 4, 7 - leaves of elongated gemmiferous shoot apices; 6 - suberect gemmiferous shoot with reduced leaves; 8 - cells of margin of leaf middle; 9 - two leaves; 10 - cells of leaf middle; 11 - habit, postical aspect; 12 - cells of leaf base; 13 - an enlarged leaf. All from China, Yunnan Province, 6.VI.1993 Long \# 24067 (KPABG).

HOLLINGSWORTH 2006. Morphological, ecological and genetic evidence for distinguishing Anastrophyllum joergensenii Schiffn. and A. alpinum Steph. (Jungermanniopsida: Lophoziceae). - J. Bryol. 28: 108-117.

MÜLLER, K. 2005. SeqState. Primer design and sequence statistic for phylogenetic DNA datasets. - Appl. Bioinformatics 4: 65-69.

SCHILL, D. \& D.G. LONG 2002. Anastrophyllum lignicola (Lophoziaceae), a new species from the Sino-Himalaya, and $A$. hellerianum new to China. - Ann. Bot. Fennici 39: 129-132.

SCHILL, D. \& D.G. LONG 2003. A revision of Anastrophyllum (Spruce) Steph. (Jungermanniales, Lophoziaceae) in the Himalayan region and western China. - J. Hattori Bot. Lab. 94: 115-157.

SCHILL, D.B., D.G. LONG, M. MOELLER \& J. SQUIRRELL 2004. Phylogenetic relationships between Lophoziaceae and Scapaniaceae based on chloroplast sequences. - Monographs in Systematic Botany from the Missouri Botanical Garden 98: 141-149.

TAMURA K., D. PETERSON, N. PETERSON, G. STECHER, M. NEI
\& S. KUMAR 2011. MEGA5: Molecular Evolutionary Genetics Analysis Using Maximum Likelihood, Evolutionary Distance, and Maximum Parsimony Method. - Mol. Biol.Evol. 28: 2731-2739.

VILNET A. A., N. A. KONSTANTINOVA \& A. V. TROITSKY 2010. Molecular insight on phylogeny and systematics of the Lophoziaceae, Scapaniaceae, Gymnomitriaceae and Jungermanniaceae. - Arctoa 19: 31-50.

VILNET, A., N. KONSTANTINOVA \& A. TROITSKY 2012. Molecular phylogenetic data on reticulate evolution in the genus Barbilophozia Löske (Anastrophyllaceae, Marchantiophyta) and evidence of nonconcerted evolution of rDNA in Barbilophozia rubescens allopolyploid. - Phytotaxa 49. 6-22.

YATSENTYUK, S.P., N.A. KONSTANTINOVA, M.S. IGNATOV, J. HYVÖNEN \& A.V. TROITSKY 2004. On phylogeny of Lophoziaceae and related families (Hepaticae, Jungermanniales) based on trnL$\operatorname{trn} \mathrm{F}$ intron-spacer sequences of chloroplast DNA. - Monographs in Systematic Botany from the Missouri Botanical Garden. 98: 150-167. 